\title{
Physico-chemical and Rheological Properties of Karaya Gum (Sterculia urens Roxb.)
}

\author{
Pooja Sahu $^{1 *}$, P.S. Pisalkar ${ }^{1}$, S. Patel ${ }^{1}$ and Pratibha Katiyar ${ }^{2}$ \\ ${ }^{1}$ Department of Agricultural Processing and Food Engineering, SVCAET \& RS, \\ FAE, IGKV, Raipur-492012, Chhattisgarh, India \\ ${ }^{2}$ Department of Plant Physiology, Agri. Bio-chemistry Medicinal Aromatic Plants, \\ COA, IGKV, Raipur-492012, Chhattisgarh, India
}

*Corresponding author

\section{Keywords}

Karaya Gum (Sterculia urens), Rheological properties

\section{Article Info}

Accepted: 07 March 2019 Available Online: 10 April 2019

\section{A B S T R A C T}

Physico-chemical and rheological properties of any material are important from industrial point of view in order to understand the requirement of different process operations for its value addition as well as for its commercial utilization. The present study describes some of the important physico-chemical and rheological properties of Karaya gum. Efforts have been made to determine moisture content, bulk density, true density, tap density, bulkiness, porosity, Hausner's ratio, Carr's compressibility index $(\%)$, angle of repose $\left({ }^{\circ}\right)$, coefficient of friction (n) on glass, mild steel, plywood and rubber surfaces following the established methods for other similar food materials. The lumps of Karaya gum collected from the forest of Chhattisgarh were used in the present study. Both grits and powder samples were used for determination of the properties depending on the demand of the methodology. The values of different physical and chemical properties determined were; moisture content: $17.47 \pm 0.44(\% \mathrm{wb})$, bulk density: $0.79 \pm 0.02\left(\mathrm{~g} / \mathrm{cm}^{3}\right)$, true density: $1.50 \pm 0.17$ $\left(\mathrm{g} / \mathrm{cm}^{3}\right)$, tap density: $0.90 \pm 0.04\left(\mathrm{~g} / \mathrm{cm}^{3}\right)$, bulkiness: $1.26 \pm 0.03\left(\mathrm{~cm}^{3} / \mathrm{g}\right)$, porosity: $46.76 \pm$ $6.12(\%)$, hausner's ration: $1.14 \pm 0.06$, carr's compressibility index: $12.31 \pm 4.19$, angle of repose: $47.27 \pm 2.91^{\circ}$, coefficient of friction $0.24 \pm 0.03 \mathrm{~N}$ (glass), $0.43 \pm 0.04 \mathrm{~N}$ (mild steel), $0.28 \pm 0.01 \mathrm{~N}$ (plywood) and $0.47 \pm 0.04 \mathrm{~N}$ (rubber), respectively. Values of ash content, $\mathrm{pH}$, refractive Index, water activity, water holding capacity (per $100 \mathrm{ml}$ ), nitrogen (\%) and protein (\%) were determined to be $4.62 \%, 4.26,1.336,0.651,84.76,0.16$ and 1.06, respectively. Karaya Gum is soluble in hot and cold water but insoluble in acetone, chloroform and ethanol. The viscosity of $1 \%$ Karaya gum solution was found to be varied from 619 to $1286 \mathrm{cp}$ in the spindle rotational speed range of 20 to 100 revolutions per minute at room temperature of $24-26^{\circ} \mathrm{C}$.

\section{Introduction}

Karaya tree is a native of dry deciduous forests of dry rocky hills land having tropical climate (Sao, 2013). It's height up to $15 \mathrm{~m}$. The flower bloom from February to March and the tree bears star shaped flowers (Gupta et al., 2011). One of the most important forest 
products of our country is Karaya gum. Karaya gum is the dried exudates obtained from the stem and branches of Sterculia tree, family Sterculiaceae. The gum is produced by genus Sterculia and is collected after tapping or blazing the tree or as natural exudates (A. Elkhalifa, A/ Wadoud and Ahmed Hassan, El Fatih). It is also known as Indian tragacanth and obtained from Sterculia urens Roxburgh. Local name of Karaya gum is Gulu, Kadaya, Karaya, Katera, Kullo and Tapsi. Chemically, Karaya gum is an acid polysaccharide composed of the sugars galactose, rhamnose and galacturonic acid.

Karaya gum has been used commercially for about 100 years. Its use became wide spread during the early 20th century when it was used as an adulteration or alternative to tragacanth gum. Further, Karaya gum was less expensive. Traditionally, India is the largest producer and exporter of Karaya gum (Gupta et al., 2011). Globally, Karaya gum trees are found in South Africa, Australia, Pakistan, Panama, Phillippines, Indonesia, Senegal, Sudan and Vietnam. In India, there are 12 Karaya gum species, of four species are available in Andhra Pradesh. They are $S$. fotieda, S. populiana, S. vilosa and S. urens. Only Sterculia urens is tap for gum harvesting. In India, producing states are Andhra Pradesh, Maharastra, Gujarat, Orissa, Rajasthan, Karnataka, Bihar and Chhattisgarh. Karaya gum trees are commercially found in the forest areas of Dantewada of Chhattisgarh state. Besides this, a few number of Karaya gum trees have also been found in Kanker, Jagdalpur, Bijapur, Sukma, Korea and Gariyaband forests (Gupta et al., 2011). In Chhattisgarh, total production of Karaya gum was around 19.9 ton during 2012-13. In India, production 1500 tons per annum and $90 \%$ of it are exported to Europe and US. Annual world production is estimated at 5500 Tons, while India's share is around 3000 - 3500 tons. It is an important raw material in the textile cosmetic, food, pharmaceutical and other industries (Kuruwanshi et al., 2017).

Karaya gum such an important for forest area (NTFP) of villagers and farmers to raise economical state. The present studies of engineering properties of any material are important from industrial point of view in order to understand the requirement of different process operations for its value addition as well as for its commercial utilization. However, study on physicochemical and rheological properties of Karaya gum (Stericulia urens) are focused in present piece of work.

\section{Collection of materials}

The sample was collected from Network Project on Harvesting, Processing and Value Addition of Natural Resin and Gums (Fig. 1).

\section{Materials and Methods}

\section{Experiment site}

The work was carried out in Dr. R. H. Richhariya Research laboratory and Department of Agricultural Processing and Food Engineering, Swami Vivekananda College of Agricultural Engineering and Technology and Research Station, Faculty of Agricultural Engineering, Department of Plant Physiology, College of Agriculture, Indira Gandhi Krishi Vishwa Vidhyalaya, Raipur (Chhattisgarh).

\section{Moisture content}

The moisture content of Karaya gum was determined by the method described by AOAC (1984). A clean crucible was dried in an air oven at 1050C, 25 and cooled in a desiccator and weighed. Two grams $(2.0 \mathrm{~g})$ of finely ground sample was accurately weighed and transferred into crucible. The crucible 
containing the sample was dried in an oven and weighed regularly till constant weight (Shekarforous et al., 2015). The moisture content was calculated using the following expression:

$M C=\frac{W_{m}}{W_{m}+W_{\alpha}} \times 100$

Where, $\mathrm{W}_{\mathrm{m}}=$ wt of moisture $(\mathrm{g}), \mathrm{W}_{\mathrm{a}}=$ weight of bone dry material, $(\mathrm{g})$

\section{Bulk density}

Bulk density of powder was determined by using measuring cylinder. Density can be calculated as weight of the powder divided by the volume acquired by that weighed powder. The SI unit of density is $\mathrm{g} / \mathrm{cm}^{3}$ (Yadav et al., 2015).

\section{True density}

Among the various methods available for the determination of true density, the liquid displacement method is the simplest method and was used in the present study (Farooq et al., 2014).

\section{Tap density}

The difference between the bulk density and tap density is only that, in bulk density we have to use the bulk volume whereas in the tap density we have to use tap volume which can be obtained by tapings 50 times (Yadav et al., 2015)

\section{Bulkiness}

The reciprocal of bulk density is called bulkiness (Yadav et al., 2015). It was calculated by the following equation:

Bulkiness $=\frac{1}{\text { bulk density }}$

\section{Porosity}

The porosity may be defined as the ratio of difference between true density and bulk density of grits and true density. According to Mohsenin (1978), porosity $(\varepsilon)$ can be expressed as follows (Fos'hat et al., 2011):

$\varepsilon=\left(1-\frac{\rho_{\mathrm{b}}}{\rho_{\mathrm{t}}}\right) \times 100$

where, $\rho_{b}=$ bulk density, $\mathrm{g} / \mathrm{cm}^{3} \rho_{t}=$ true density, $\mathrm{g} / \mathrm{cm}^{3}$

\section{Hausner's ratio}

It may be defined as ratio of tap density and bulk density (Yadav et al., 2015).

Hausner Ratio $=\frac{\text { Tap density }}{\text { Bulk density }}$

\section{Carr's compressibility index}

The Carr's Compressibility index was determined using following formula (Yadav et al., 2015):

Carr's Compressibility Index $=\frac{\text { Tap density }- \text { Bulk density }}{\text { Tap density }}$

\section{Angle of repose}

This apparatus consists of a circular platform immersed in a box filled with Karaya gum grits and glass window in one side. The platform is supported by three adjustable screw legs and is surrounded by a metal funnel leading to a discharge hole. The grits allow escaping from the box, leaving the free standing cone of grits on the platform. The angle of repose was determined using the standard procedure and calculation was carried out using following formula (Yadav et al., 2015): $\theta=\tan ^{-1} \frac{\mathrm{h}}{\mathrm{r}}$ where, $\theta=$ angle of repose $\left(^{\circ}\right), \mathrm{h}=$ height $(\mathrm{cm}), \mathrm{r}=$ radius of circular plate $(\mathrm{cm})$ 


\section{Coefficient of friction}

The static coefficient of friction of Karaya gum grits was measured for four frictional surfaces, namely glass, rubber, plywood, and mild steel. A fiberglass topless and bottomless box of $0.15 \mathrm{~m}$ length, $0.10 \mathrm{~m}$ width, and 0.04 $\mathrm{m}$ height was placed on an adjustable inclined plane, faced with the test surface and filled with the sample. The box was raised slightly $(5-10 \mathrm{~mm})$, so as not to touch the surface. The structural surface with the box resting on it was inclined gradually with a screw device until the box just started to slide down over the surface and the angle of tilt $(\alpha)$ was read from a graduated scale (Razavi et al., 2006). The static coefficient of friction $\left(\mu_{\mathrm{s}}\right)$ was then calculated from the following equation (Mohsenin, 1978): $\mu_{s}=\tan \alpha$

\section{Ash content}

$5 \mathrm{~g}$ of gum sample was first heated on a burner in air to remove its smoke. Then it was burned in a furnace at $550^{\circ} \mathrm{C}$. The ash content was expressed as a \% ratio of the mass of the ash to the oven dry mass (Yusuf, 2011).

\section{Determination of $\mathbf{p H}$}

The sample powder was thoroughly mixed and $1 \mathrm{~g}$ and was dissolved in $100 \mathrm{ml}$ of hot distilled water. The mixture was allowed to stand for $5 \mathrm{~min}$ at room temperature before the $\mathrm{pH}$ and temperature was recorded using a pre-calibrated pH meter (Ameh, 2012).

\section{Water holding capacity}

One g powder of gum Karaya was suspended in $10 \mathrm{ml}$ of distilled water, vortexes for $2 \mathrm{~min}$ and then centrifuged with a refrigerated centrifuge $3-18 \mathrm{~K}$ at $3,000 \mathrm{~g}$ for $30 \mathrm{~min}$. Water holding capacity (WHC) was calculated based on the following equation (Mirhosseini and Amid, 2012):

$$
\mathrm{WHC}=(\mathrm{SSW}-\mathrm{SW}) / \mathrm{SW}
$$

Where, $\quad$ SSW = water swollen sample weight $(\mathrm{g}), \mathrm{SW}=$ sample weight $(\mathrm{g})$

\section{Determination of water sorption}

In order to determine the water sorption capacity of the gum, dried evaporating dishes were weighed and $2.0 \mathrm{~g}$ of each of the gum samples was weighed into the different dishes. The final weight of the dishes was noted and placed over water in desiccators. After 5 days, the dish was transferred to other desiccators over activated silica gel (desiccant) for another 5 days. The percentage sorption was calculated by difference in weight (Eddy et al., 2012).

\section{Refractive index}

Refractive Index of sample was dimensionless number and it can provide information for us about the behavior of light. Refractive index of gum samples was measured in a filtered $1 \%$ aqueous solution using a digital refractometer (El - Kheir et al., 2008).

\section{Water activity}

Water activity $\left(\mathrm{a}_{\mathrm{w}}\right)$ was determined using a AquaLab Lite water activity meter at room temperature (García-Cruz et al., 2012).

\section{Determination of solubility}

The solubility of the gum was determined in cold and hot distilled water, acetone, chloroform, and ethanol. $1.0 \mathrm{~g}$ sample of the gum was added to $50 \mathrm{ml}$ of each of the above mentioned solvents and left overnight. $25 \mathrm{~mL}$ of the clear supernatants were taken in small pre-weighted evaporating dishes and heated to dryness over a digital thermostatic water bath. The weights of the residue with reference to the volume of the solutions were determined 
using a digital top loading balance and expressed as the percentage solubility of the gums in the solvents (Eddy et al., 2012).

\section{Nitrogen and protein content}

Nitrogen was determined by semi-micro Khjedal methods (AOAC, 1990). Protein content was calculated using a nitrogenconversion factor of 6.6 (Yusuf et al., 2011).

$$
\begin{aligned}
& \mathrm{N} \%=\frac{\text { (Volume of sulphonic acid }- \text { Volume of blank }) \times 14 \times \text { Nomality }(\mathrm{N}) \times 100}{\text { sample weight } \times 1000} \\
& P \%=N \% \times 6.6
\end{aligned}
$$

\section{Viscosity measurement}

The viscosity was determined and calculated for the $1 \%$ solution of the mucilage at $30^{\circ} \mathrm{C}$ temperature and various rotational speeds by using spindle 63 of digital Brookfield DV-E viscometer (Yadav et al., 2015).

\section{Results and Discussion}

Table 1 and 2 shows some of the physicochemical parameters of Karaya gum. Food moisture analysis plays a significant role in the modern world. The moisture content of Karaya gum was low, suggesting its suitability in formulations containing moisture sensitive foodstuff. It is important to investigate the moisture content of a material because the economic importance of an food for industrial application lies not only on the cheap and ready availability of the biomaterial but the optimization of production processes such as drying, packaging and storage.

Ash values reflect the level of adulteration or handling of the foodstuff. Adulteration by sand or earth is immediately detected as the total ash is normally composed of inorganic mixtures of carbonates, phosphates, silicates and silica. Therefore, the low values of total ash obtained in this study indicate low levels of contamination during gathering and handling of crude Sterculia urens.

The bulk and tap densities observed and shown in table 1 it give an insight on the packing and arrangement of the particles and the compaction profile of a material. The Houser's ratio, compressibility Index and angle of repose of Karaya gum were $1.14 \%$, $12.31 \%$ and $47.27^{\circ}$ respectively, implying that the Karaya gum has a good flow with moderate compressibility. It is important in scale up processes involving this material as an excipient in a pharmaceutical formulation, cosmetic and food beverages. Modification of formulations containing this gum for the improvement of flow properties during process development will therefore be minimal compared to GA (e.g., inclusion of glidants or agents to aid in feeding). Porosity value of Karaya gum powder shown in table 1 is $46.76 \%$ it indicated that the number of voids in the sample is minimum it present low air space. Coefficient of friction of Karaya gum determined in four different surfaces like glass, mild steel, plywood and rubber and its average observation indicates that the friction is critical to ensuring reliable flow. In rubber surface highest coefficient of friction and followed mild steel, plywood and glass surfaces.

Water activity of gum Karaya was measured at room temperature and result obtained was 0.651 (Table 2). It is a critical factor affecting the shelf life of the product which controlling the behavior for intermediate and low moisture food during processing and storage. The Karaya gum is soluble in water and practically insoluble in ethanol, acetone and chloroform but higher solubility in hot water it indicating that the solubility of the gum is temperature dependent. Since solubility is expected to increase with increase in temperature, the solubility of the gum in hot 
water is higher than the corresponding solubility in cold water. On the other hand, the samples were not soluble in acetone and chloroform but sparingly soluble in ethanol (Ameh, 2012). The good solubility of these gums is also indicative of the absence of cross linking between polymeric chains. This is because gums having cross linked polymeric chains only swell in water, without dissolving (Yusuf, 2011). The water sorption capacity was calculated and result obtained is $0.885 \%$ (Table 2). The water sorption of gum Karaya was increased continue up to the fifth day of immersion (i.e., 100\% RH over water) and dropped sharply within 24 hours when subjected to action of desiccant. By the fifth day desiccant environment, water content of gums had reduced considerably $1-3 \%$. It is indicated that if the gum are stored in a damp environment, the gums will quickly be hydrated and also have the tendency to rapidly loose such water molecules in the presence of desiccants (within five days). The observed result is consistent with the findings of Eddy et al., (2012).

Table.1 Physical properties of gum Karaya

\begin{tabular}{|c|c|}
\hline Physical parameters & Results \\
\hline Moisture Content (\%wb) & $17.47 \pm 0.44$ \\
\hline Bulk density (g/ml) & $0.79 \pm 0.02$ \\
\hline True density (g/ml) & $1.50 \pm 0.17$ \\
\hline Tapped density (g/ml) & $0.90 \pm 0.04$ \\
\hline Bulkiness (ml/g) & $1.26 \pm 0.03$ \\
\hline Porosity (\%) & $46.76 \pm 6.12$ \\
\hline Hausner's Ratio & $1.14 \pm 0.06$ \\
\hline Carr's Compressibility Index (\%) & $12.31 \pm 4.19$ \\
\hline Angle of repose $\left(^{\circ}\right)$ & $47.27 \pm 2.91$ \\
\hline \multicolumn{2}{|l|}{ Coefficient of friction $(\mathbf{N})$} \\
\hline Glass & $0.24 \pm 0.03$ \\
\hline Mild Steel & $0.43 \pm 0.04$ \\
\hline Plywood & $0.28 \pm 0.01$ \\
\hline Rubber & $0.47 \pm 0.04$ \\
\hline
\end{tabular}

Table.2 Physicochemical properties of gum Karaya

\begin{tabular}{|l|c|}
\hline \multicolumn{1}{|c|}{ Physicochemical Parameters } & Result \\
\hline Ash Content (\%) & 4.62 \\
\hline pH & 4.26 \\
\hline Refractive Index & 1.336 \\
\hline Water Activity & 0.651 \\
\hline Solubility (per 100 ml) & \\
\hline \multicolumn{1}{|c|}{ Hot Water } & 27.22 \\
\hline Cold Water & 9.84 \\
\hline Acetone & 0.00 \\
\hline Chloroform & 0.00 \\
\hline$\quad$ Ethanol & 0.00 \\
\hline Water Sorption Capacity (\%) & 0.89 \\
\hline Water Holding Capacity (per 100 ml) & 84.76 \\
\hline Nitrogen (\%) & 0.16 \\
\hline Protein (\%) & 1.06 \\
\hline
\end{tabular}


Fig.1 (a) Karaya gum lumps (b) Karaya gum grits (c) Map of potential area (d) Karaya gum tree
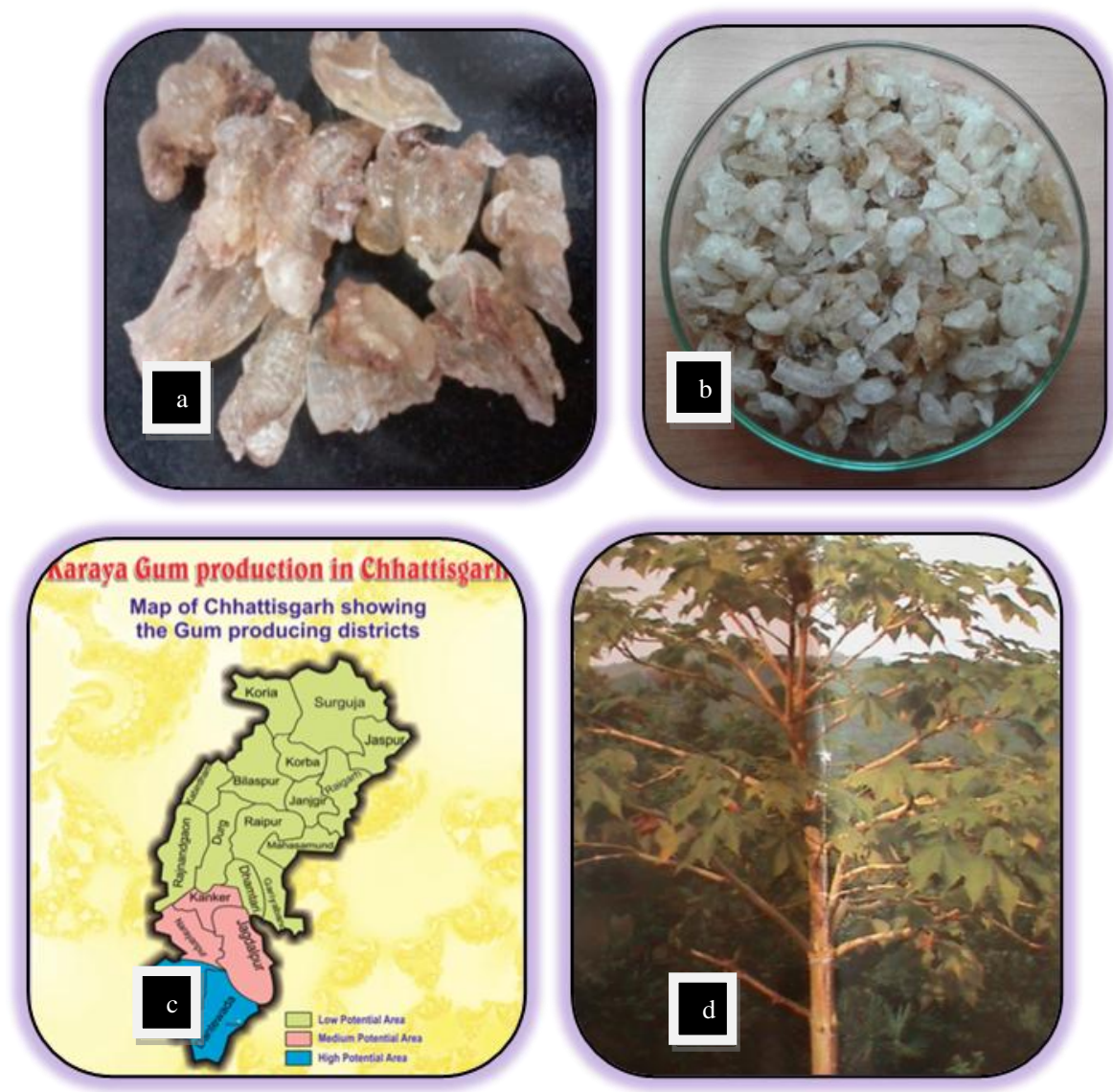

Fig.2 Viscosity (cp) versus speed rotation (rpm)

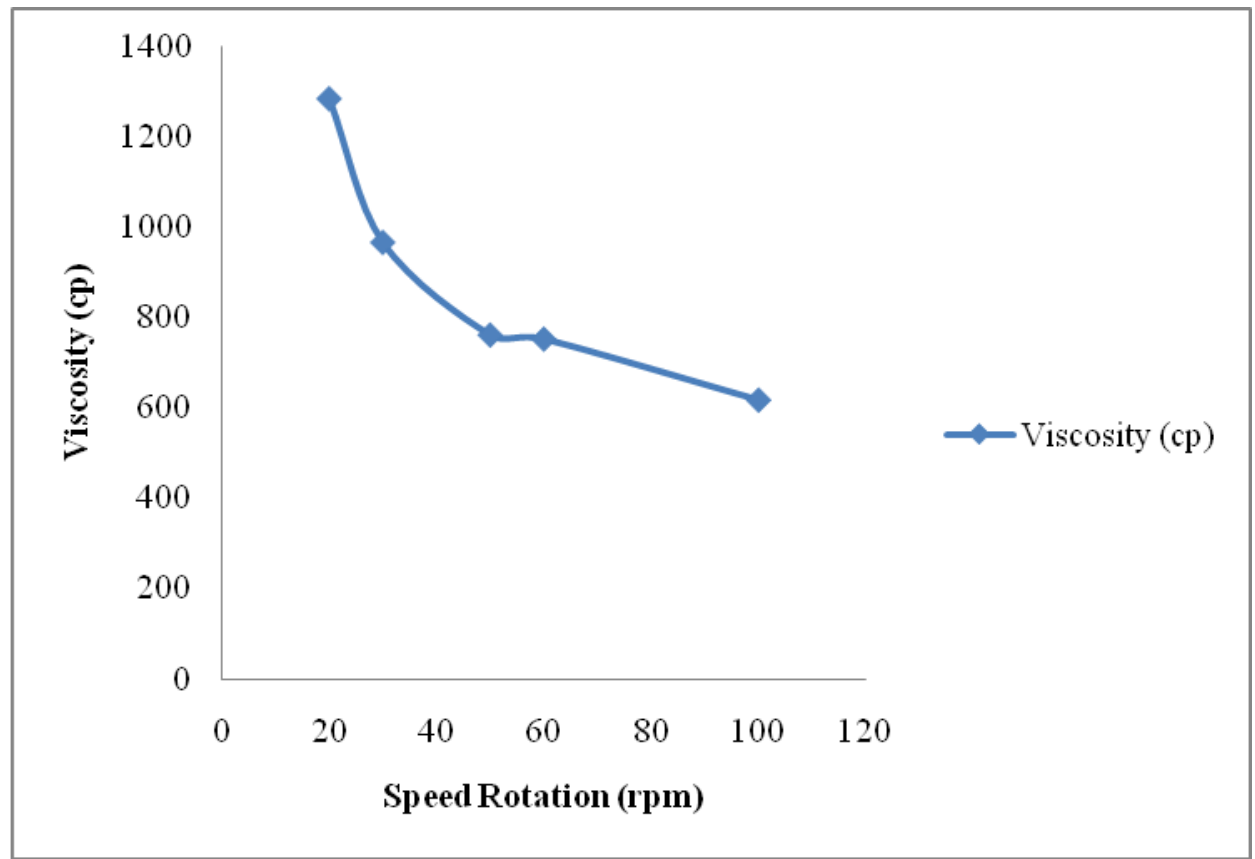


The $\mathrm{pH}$ value of Karaya gum shows low acidic nature the $\mathrm{pH}$ value of 4.5 is in good agreement with reported $\mathrm{pH}$ values for gum Arabic and other Acacia gums by several authors and refractive Index value 1.336 is similar to those reported by Taha et al., (2009), Ahmed et al., (2009) and El-kheir et al.,(2008). Water holding capacity value shows by analysis about $84.76 \%$ is nearly according to Taha et al., (2012) for three types of gum from Sudan and Ahmed et al., (2009) for Anogeissus leiocarpus gum. Nitrogen and protein content value is almost similar by authors Elkhalifa and Hassan (2010) and Adeleye et al., (2015). Figure 2 shows the plot of viscosity versus the rotation speed at $1 \%$ concentration of gum solution. From Figure 2 it was observed that the viscosity of gum decrease with increase in speed of rotation (rpm). The values of viscosity were obtained 1286, 968, 763, 754 and $619 \mathrm{cp}$ for rotational speed 20,30, 50, 60 and $100 \mathrm{rpm}$. Gum Karaya gives rise to highviscosity solutions even at $1 \%$ concentration.

In conclusion, the quality and applicability of well characterized materials are directly related to their physical and chemical properties. The results of this study support the gum suitability for industrial application, especially in areas where commercial Karaya gum is traditionally used. The physicochemical profile of the Karaya gum sample studied and the wide availability of the raw materials in Chhattisgarh State and other States. The results obtained in this study established for the first time, the fundamental characteristics of Karaya gum. The present investigation is a primary platform to indicate the suitability of Karaya gum as a binding agent.

\section{Acknowledgements}

The authors are grateful to the Department of Agricultural Processing and Food
Engineering, plant physiology, Agri. BioChemistry Medicinal Aromatic Plants and Dr. R. H. Richhariya Research laboratory, Swami Vivekananda College of Agricultural Engineering and Technology and Research Station, Faculty of Agricultural Engineering, Indira Gandhi Krishi Vishwavidyalaya, Raipur (Chhattisgarh) for moral support and to provide essential facility.

\section{References}

Adeleye, Olutayo A., Femi-Oyewo, Mbang N., and Odeniyi, Michael A. 2015. Physicochemical and rheological characterization of Cissus populnea gum extracted by different solvents. West African J. of Pharmacy 26 (1) 113-126.

Ademoh, Nuhu A. and Abdullahi, A.T. (2009). Determination of the physiochemical properties of Nigerian Acacia species for foundry sand binding applications. Research $\mathbf{J}$ of Applied Sciences, Engineering and Technology. 1(3) 107-111.

Ahmed, Samia Eltayeb, Mohamed, Babiker Elwasila and Karamalla, Karamalla Ahmed. (2009). Analytical studies on the gum exudates from Anogeissus Leiocarpus. Pakistan J. of Nutrition. 8(6) 782-786.

Ahmed, Samia Eltayeb. 1999. Analytical studies on the gum exudate from Anogeissus leiocarpus. PHD Thesis. University of Khartoum.

Ameh, Paul Ocheje. 2012. Physicochemical properties and rheological behavior of Ficus glumosa gum in aqueous solution. International J. of Modern Chemistry 2(3): 84-99.

Dafam, D.G., Abubakar, M.S., Nuhu, H., Ajima, U., and Okwori, V. (2013). Quantitative evaluation of some physical and chemical properties of the gum-mucilage of Anacardium 
Occidental L (Anacardiaceae). International J. of Pharmaceutical Science Invention 2 (9) 46-48.

Doymaz, Ibrahim. (2014). Drying kinetics and rehydration characteristics of convective hot-air dried white button mushroom slices. J. of Chemistry. Volume 2014 01-09.

Eddy, Nnabuk O., Ameh, Paul O., Gimba, Casimir E. and Ebenso, Eno E. (2012) Rheological Modeling and Characterization of Ficus platyphylla Gum Exudates. J. of Chemistry. 1-10.

Elkhalifa, A/Wadoud A. and Hassan, El Faith Ahmed. (2010). Characterization of Sterculia setigera gum (gum karaya) in Sudan. University of Africa J. of Science. 1(1) 18-26.

El-Kheir, Murwan K. Sabah, Yagoub, Abu El Gasim A. and Baker, Asma A. Abu. (2008). Emulsion-stabilizing effect of gum from Acacia Senegal Willd. The role of quality and grade of gum, oil type, temperature, stirring time and concentration. Pakistan J. of Nutrition. 7(3) 395-399.

Elnour, Ahmed Adam, Elsayed, Mohamed E. Osman, Isag, K.E.A., Abdalla, Abdalla Abdelsamad and H.E., Adam. (2009). Physicochemical Properties of Acacia Polyacantha Gum. University of Hamburg, Conference on International Research on Food Security, Natural Resource Management and Rural Development. 1-4.

Farahnaky, A., N., Darabzadeh, M., Majzoobi, Gh., Mesbahi, E., Rezvani and G., Schleining. (2013). Production and rheological properties of locust bean gum from Iranian carob seeds. Insidefood symposium. 1-6.

Farooq, Uzma, Malviya, Rishabha and Sharma, Pramod Kumar. (2014). Extraction and characterization of Artocarpus integer gum as pharmaceutical excipient. Polim. Med.
44 (2) 69-74.

Ghadge, Prashant N. and Prasad, K. (2012). Some physical properties of rice kernels: variety PR-106. J of Food Processing and Technology. 3(8) 01-05.

Higiro, J., Herald, T.J. and Alavi, S. (2005). Rhelogical study of xanthan and locust bean gum interaction in dilute solution. Food Research International. (39) 165 175.

Ibrahim, Omar B., Osman, Mohamed E. and Hassan, Elfatih A. (2012). Characterization and simple fractionation of Acacia Senegal. J. of Chemical Acta. 2(2013) 11-17.

Jha, R.K., Prabhakar, P.K., Srivastav, P.P. And Rao, V.V. (2015). Influence of temperature on vacuum drying characteristics, functional properties and micro structure of aloe vera (Aloe Barbadensis Miller) Gel. Research Agr. Eng. 61(4) 141-149.

LoÂpez-Franco, Y. and Higuera-Ciapara, I. (2013). Other exudates: Tragancanth, Karaya, mesquite gum and larchwood Arabinogalactan. Handbook of hydrocolloids. p. 495-534.

Mhinzi, Gaspar S. (2001). Properties of gum exudates from selected Albizia species from Tanzania. Food Chemistry. 77(2002) 301-304.

Munoz, Jose, Rincon, Fernando, Alfaro, M. Carmen, Zapata, Isabel, Fuente, Julia de la, Beltran, Olga and Pinto, Gladys Leon de. 2007. Rheological properties and surface tension of Acacia tortuosa gum exudate aqueous dispersion. Carbohydrate Polymers 70 (2007) 198205.

Parveen, Kousar, Vasandan, A.G.M., Memon, Zuhra, Memon, Fahmida and Moghal, M. A. (2014). International Organization of Scientific Research J. of Engineering (IOSRJEN). 4(12) 5460.

Rahimi, Somayeh, Abbasi, Soleiman, Sahari, 
Mohammad Ali and Azizi, Mohammad Hossein. (2013). Characterization of an unknowm exudates gum from Iran: Persian Gum. 1-5.

Sahu, Phagu Ram (2015). Comparative evaluation of turmeric processing methods and standardization of process technology. M. Tech. Thesis. Indira Gandhi Krishi Vishwavidyalaya Raipur. p. 32-35.

Sarathchandiran, I, and P, Suresh Kumar. (2014). Characterization and standardization of gum Karaya. International J. of Biopharmaceutics. 5(2) $142-151$.

Shekarforoush, Elhamalsadat, Mirhosseini, Hamed, Amid, Bahareh Tabatabaee, Ghazali, Hasanah, Muhammad, Kharidah, Sarker, Zaidul Islam and Paykary, Maryam. (2015). Rheological properties and emulsifying activity of gum karaya (Sterculia Urens) in aqueous system and oil in water $(\mathrm{o} / \mathrm{w})$ emulsion: heat treatment and microwave modification. International J. of Food Properties. Pp. 1-47.

Singh, Anoop Kumar, Selvam, R. Panner and Sivakumar, T. (2010). Isolation, characterisation and formulation properties of a new plant gum obtained from magnifera indica. International $\mathbf{J}$. of Pharmaceutical and Biomedical Research. 1 (2) 35-41.

Singh, Jaspreet and Singh, Balwinder. (2014). Drying kinetics of gum Karaya (sterculia urens) using convective air dryer. British J. of Pharmaceutical Research. 4(13) 1647-1656.

Taha, K.K., Elmahi, R.H., Hassan, E.A., Ahemad, S.E. and Shyoub, M.H. 2012. Analytical study on three types of gum from Sudan. J. of Forest Products \& Industries 1(1):11-16.

Vinod, VTP and Sashidhar, R B. (2009). Surface morphology, chemical and structural assignment of gum Kondagogu (Cochlospermum gossypium DC.): An exudate gum tree of India. Indian J. of Natural Products and Resources. 1(2) 181-192.

Yadav, Sandeep, Sharma, Pramod K. and Goyal Narendra K. (2015). Comparative study of mucilage extracted from seeds of cassia fistula and gum Karaya. Advances in Biological Research. 9(3) 177-181.

Yusuf, A.K. (2011). Studies on some physicochemical properties of the plant gum exudates of Acacia senega (Dwkwara), Acacia sieberiana (Farar Kaya), and Acacia nilotica (Bagaruwa). JORIND 9(2).

\section{How to cite this article:}

Pooja Sahu, P.S. Pisalkar, S. Patel and Pratibha Katiyar. 2019. Physico-chemical and Rheological Properties of Karaya Gum (Sterculia urens Roxb.). Int.J.Curr.Microbiol.App.Sci. 8(04): 672-681. doi: https://doi.org/10.20546/ijcmas.2019.804.072 